\title{
HET TWEede VERSLAG DER NEDERLANDSCHE BANK.
}

Het is zeker een aangename taak roor het bestuur van een maatschappij om verslag uit to brengen over hetgeen in het afi geloopen boekjaar is voorgevallen, wanneer men aan zijne aandeelhouders zulke verblijdende resultaten heeft mede te deelen als de president der Nederlandsche Bank den 16 Mei laatstl. in staat was te doen. En niet minder moet het voor die vennooten zelve streelend zijn, zulke verblijdende mededeelingen aan to hooren. Het is nu toch weder gebleken, dat de belangrijke rijzing, die in den laatsten tijd in de aandeelen der Nederlandsche Bank heeft plaats gegrepen, volstrekt niet op Schwindel, zelfs op geen , höheren Schwindel" berustte, maar integendeel volkomen gewettigd was. Het dividend van $f \mathbf{1 8 5}$, dat thans is uitgekeerd, geeft aan hen, die voor $250 \mathrm{pCt}$. deelhebbers zijn geworden nog altijd een rente van meer dan $7 \mathrm{pCt}$.

Het Jaarverslag van den president is, gelijk wij het mochten verwachten, degelijk en business-like. Zonder onnoodigen omhaal wordt ons medegedeeld wat wij wenschen te weten en voor mededeeling vatbaar was. De veranderingen in het bestuur, het getal der deelhebbers, de voortgang van het bouwwerk, den omvang der operatiën, den gemiddeldem rentestand, de oorzaken die tot veranderingen in dezen laatsten hebben aanleiding gegeven, worden achtereenvolgens besproken. Daarop wordt te onzer kennis gebracht hoeveel aan wissels en hooveel aan "ander papier" is gedisconteerd, welk aandeel de Agentschappen en de Bijbank in de bewegingen der portefeuille hebben gehad, en welke verliezen de Bank door hare disconto's heeft geleden. Ook omtrent de beleeningen worden soortgelijke mededeelingen gedaan. Eindelijk komt de speciehandel aan de orde, waarna met eenige opgaven betreffende de bankbilletten, de bankassignatiën, de rekening-courant-saldo's, het reservefonds, en - last not least - de winst- en verlies- 
rekening, het rapport wordt besloten. Als aanhangsel dienen, behalve het verslag der commissarissen en de balans, eenige statistische tabellen, welker samenstelling, zoo wat vorm als inhoud betreft, voorzeker weinig te wenschen overlaten.

Het zou overbodig zijn aan dezen korten index een breedvoerig uittreksel too te voegen, daar het stuk zelf tot den billijken prijs van 50 cents voor een ieder verkrijgbaar is. Wij willen daarom slechts op enkele van de voornaamste punten ter loops de aandacht vestigen. Vooreerst wenschion wij opmerkzaam te maken op de ververbeteringen die in dit verslag, vergelek'en bij dat van het vorige' boekjaar, zijn aangebracht. Men is nu eindelijk in staat gesteld te: beoordeelen, hoeveel de Bank aan wisselbrieven en hoeveel aan ander papier elke maand heeft gedisconteerd en welke verhouding er heeft bestaan tusschen de goederen en effecten-beleeningen. Deze opgaven zijn inderdaad zeer belangrijk te noemen. Het blijkt thans - om eerst van de disconto's te spreken - dat het gezamentlijk bedrag van deze laatsten tot ruim $f 242$ millioenen is yeklommen en dat de promessen enz. hierin voor $f 81$ millioen, dus ongeveer voor een derlle hebben gedeeld. Deze proportie is zeer aanzienlijk; want, volgens het verslag van den president, bedroegen de disconto's van "ander handelspapier" in 1864/5 ruim $f 21$ millioen minder; dus moet dé splitsing toenmaals als volgt zijn geweest:

$$
\begin{aligned}
& \text { wisselbrieven . . . . } f 178 \text { millioen. } \\
& \text { ander handelspapier . . } \frac{-60}{f 238} \text { " }
\end{aligned}
$$

De verhouding was dus in het vorige boekjaar iets meer dan een vierde. Verder kunnen wij uit het rapport opmaken, dat de vermeerdering van circa. $f 17$ mill., die tusschen Juni en Nov. 11. in de disconto-rekening heeft plaats gevonden, voor het grootste deel in voorschotten op wissels haar oorzaak heeft gevonden. Immers

\begin{tabular}{|c|c|c|c|c|c|c|c|}
\hline \multirow[b]{2}{*}{ Juni . } & \multicolumn{4}{|c|}{ Wiasels. } & \multicolumn{3}{|c|}{ Ander papier. } \\
\hline & . & . $J$ & $f \quad 9^{81}$ & millioen & $f$ & $7^{00}$ & millioen. \\
\hline Juli . . & . & . & $-11^{8,0}$ & $n$ & - & $5^{78}$ & $n$ \\
\hline Augustus . & . & . & $-13^{01}$ & $\eta$ & - & $7^{15}$ & $\eta$ \\
\hline September & . & . - & $-15^{95}$ & $\eta$ & - & $7^{20}$ & $"$ \\
\hline Oetober & . & . & $-14^{47}$ & $n$ & - & $6^{94}$ & " \\
\hline November & . & . - & $-15^{27}$ & $n$ & - & $7^{99}$ & $\eta$ \\
\hline & & & $f 80^{11}$ & oen & & 4100 & lioen, \\
\hline
\end{tabular}
de disconteeringen bedroegen: 
Er werd dus in dat tijdsverloop gemiddeld elke maand voor $f 6 \frac{1}{2}$ millioen meer aan wissels dan aan ander papier gedisconteerd, terwijl van April tot en met Juni het verschil gemiddeld slechts $f 4^{4}$ millioen had bedragen.

Het is de moeite waard deze opgaven in verband te brengen met de straks vermelde statistiek der beleeningen. Gelijk men weet, steeg deze rekening in het vorige jaar tusschen Juni en November ongeveer $f 15$ millioen. Wij zijn thans in staat te beoordeelen in welke mate die vermeerdering aan den goederen- en in welke mate aan den effectenhandel moet worden toegeschreven. De volgende tabel, dien het niet moeilijk was uit de gegevens in het verslag samen te stellen, geeft hierover voldoende inlichtingen.

$$
\text { Datum. }
$$

$$
\begin{aligned}
& \text { Beleening } \\
& \text { op goederen. }
\end{aligned}
$$

Beleening op elfecten.

\begin{tabular}{|c|c|c|c|c|}
\hline 30 April & " & -5.73 & $"$ & -21.22 \\
\hline 31 Mei & $"$ & -5.39 & , & -19.82 \\
\hline 30 Juni & 33 & -537 & " & -2353 \\
\hline 31 Juli & " & -5.32 & \# & -25.47 \\
\hline 31 Aug. & $"$ & -5.53 & $"$ & -25.70 \\
\hline 30 Sept. & " & -6.67 & $"$ & -27.63 \\
\hline 31 Oct. & 3 & -678 & $" z$ & -32.24 \\
\hline 30 Nov. & " & -6.75 & ” & -35.05 \\
\hline 31 Dec. & " & -6.97 & $"$ & -35.34 \\
\hline 31 Jan. & 1866 & -7.20 & " & -31.67 \\
\hline 28 Febr. & " & -6.98 & " & -27.81 \\
\hline 31 Maart & $"$ & -6.63 & " & - 25.03 \\
\hline
\end{tabular}

31 Maart $1865 f 5.98$ millioen $f 20.05$ millioen.

Wij zien daaruit, namelijk, dat de bewuste vermeerdering bijna geheel moet worden toegeschreven aan beleeningen op effecten en dat de goederen hierin slechts een zeer klein aandeel hebben gehad.

Het verslag, dat wij thans voor ons hebben is het eerste, waarin mededeeling kon geschieden van de operatiën der Bijbank en agentschappen. De eerste schijnt aan de Bauk belangrijke voordeelen te hebben opgeleverd. De disconteringen toch van dat kantoor bedroegen niet minder dan $31,8 \mathrm{pCt}$. van het geheele quantum, terwijl daarentegen de agentschappen slechts $4,33 \mathrm{pCt}$. leverden. De gezamentlijke portefeuilles van deze laatsten beliepen op 31 Mart 11. $f 2^{35}$ millioen, tegen $f 2^{45}$ bij de Bijbank en $f 31^{72}$ millioen bij het hoofdkantoor. De behoefte aan disconto schijnt in de provinciën nog niet zeer belangrijk te zijn. De grootste portefeuille is die van Arnhem met $f 383,515.89 \frac{1}{2}$, de rleinste, dio van Meppel 
met $f 29,706.45$. - De beleenincyen daurentegen hebbeu bij de agentschappen meer bedragen, terwijl zij bij de Bijbank geringer waren. Van de $f 36,681,500$ gesloten effecten-posten, waren

$$
\begin{aligned}
& 54.03 \text { pCt. bij de Hoofdbank, } \\
& 18.63 " \text { " "Bijbank, } \\
& 27.34 " \text { " Agentschappen. }
\end{aligned}
$$

Van de thans loopende beleeningen is het grootste bedrag $(f 1,171,150$, waarvan $f 67,700$ op goedereu) te Groningeu, het kleinste ( $f 38,720$ ) te Maastricht geplaatst.

Het valt moeilijk uit de gegevens die in dit Rapport aanwezig zijn op to maken, in hoeverre de oprichting der agentschappen reeds nu voor de Bank een bron van voordeel is geweest. Wel blijkt ons dat

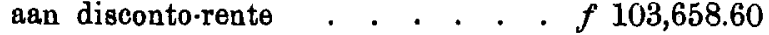

$$
\begin{aligned}
& \text { aan beleenings-rente. . . . . . - 194,165.75 } \\
& \text { te zamen in de agentschappen } f 297,824.35 \frac{1}{2}
\end{aligned}
$$

is verdiend, en deze som is drie maal grooter dan de vermeerdering ( $v a n$ circa $f 97,000$ ) die de jaarlijksche onkosten hebben ondergaan; eene vermeerdering, die natuurlijk ook voor een groot deel het gevolg is van de oprichting der Bijbank. Maar hier tegenover staat, dat gewis vele zaken nu bij de agentschappen worden afgesloten, die eertijds met het Hoofdkantoor zelf werden verhandeld, zoodat men niet zeker weet welk deel van de verdiensten als aanwinst mag worden beschouwd. Het zou wellicht aan de directio zelve moeite kosten hier een juiste grenslijn te trekken. Zooveel schijnt ten minste vast te staan dat de agentschappen niet veel extra-uitgaven veroorzaken en voorshands geen gevaar loopen een bron van verlies voor de Bank te worden. De eene plaats moge wat voordeeliger zijn dan de andere, dooreengenomen zullen de kosten wel goed gemaakt worden. En het kan niet missen of op den duur moet de uitbreiding, die de Bank uan hare inrichting gegeven heeft, bevorderlijk zijn aan de uitbreiding van hare operatiën.

Op ééne zaak heeft zij ongetwijfeld reeds gunstig gewerkt, te weten op den omloop van bankbilletten. In 1864/65 was het hoogste cijfer der circulatie $f 119^{85}$ millioeu, het gemiddelde bedrag $f 104^{85}$ millioen. Nu was het hoogste cijfer $f 122^{\circ 9}$, terwijl het gemiddeldo $f 112^{54}$, dus $f 7^{30}$ millioen meer, beliep. "Onze bijkantoren” zegt het rapport, „hebben buiten twijfel tot dien vermeerderden omloop bijgedragen. Ruime gelegenheid is overal gegeven tot verwisseling, op welke wijze die ook begeerd werd, en die gelegenheid is niet ongebruikt gelaten." Het total der verwisselingen op de bijkan- 
toren (inclusief Rotterdam) bedroeg ruim $f 58$ millioen. Hiervan namen alleen de verwisselingen van billetten tegen billetten $f 37^{20}$ milloen in beslag en het schijnt dat weder meest klein papier tegeri groot is gevraagd. De circulatie van de groote coupures toch neemt gedurig af, terwijl die der kleine daarentegen steeds vermeerdert. Op 31 Mart b. v. was.

\section{$1864 \quad 1865 \quad 1866$}

de geheele omloop van billetten $f 105^{30} \mathrm{~m} . f 103^{10} \mathrm{~m} . f 102^{26} \mathrm{~m}$. Daarvan circuleerde aan billetten $\operatorname{van} f 1000$. . . . . . $-28^{13} n-27^{40} n-20^{85} n$ Aan billetten $\operatorname{van} 100-25 .+-39^{00} "-42^{16} "-49^{3.1} "$ terwijl dus de billetten van $f 1000$ ruim $f 7,000,000$ waren verminderd, waren de kleinere billetten ruim $f 10,000,000$ toegenomen.

De handel in muntmateriaal leverde dit jaar belangrijker voordeelen op dan in 1864-65. De winst bedroeg toen $f 62,800$, nu $f 144,900$. Deze meerdere winst is het gevolg van meerderen handel. De Bank verkocht in het vorige jaar 51,665 ned. ponden fijn zilver; in dit jaar 143,050 pond. Welke soorten van zilver, hoeveel. aan vreemde munten en hoeveel aan baren, de Bank heeft verkocht, wordt ons niet medegedeeld. Wel vindt men in het verslag eene splitsing tusschen zilveren baren en per wicht verhandelde zilveren speciën ( $f 15$ millioen), Mexicaansche piasters $(f 500,000)$ en gouden baren en speciën $(f 100,000)$; doch daar de eerstecategorie bijna al het zilver bevat dat de Banke heeft verkocht, zoo laat de bedoelde opgave ors met betrekking tot het punt in questie nageno,eg geheel in het duister.

De koopprijs was als gewoonlijk $f$ 104,65 per Ned. pond fijn, de verkoopprijs steeg tot de vroeger ongekende hoogte van $f 106,05$.

Ziedaar enkele der voornaamste punten aangestipt. Wij eindigen dit overzicht met eene opmerking en een wensch.

Eene opmerking. "Aanvankelijk," dus zegt de president in zijn Rapport, sprekende van den metaalhandel, „werden niet onaan„zienlijke hoeveelheden (zilver) tegen matige prijzen verkocht. "Toen echter in het najaar de steeds stijgende wisselkoers, gepaard "gaande met een hoogen buitenlandschen prijs van zilver, den "uitvoer sterker dreigde te maken dan bij de zoo sterk toe"nemende credietrraag hier te lande wenschelijk scheen, trachtte "de directie dien gang van zaken to stuiten door den: verkoopprijs "Yan zilver alhier van lieverlede te verhoogen en bij de, crediet"operatiën der Bank een hoogere rente te vorderen." 
Door verhooging van den verkoopprijg van het zilver en door het vorderen van een hoogeren rentekoers trachtte de Bank den specievitvoer te weeren. $N u$ weet men, dat het eerste veel vroeger dan het tweede heeft plaats gevonden; de Bank heeft hare zilverprijzen verhoogd, lang vóor zij tot verhooging van disconto overging. Wij moeten dus uit de bovenstaande woorden in het verslag opmaken, vooreerst, dat de verhooging van den zilverprijs niet geschiedde om een voordeel te behalen; en vervolgens dat de Bank dàarom haar rentekoers niet vroeger heeft veranderd, omdat zij eerst wilde trachten door een ander middel, verhooging van den zilverprijs, het $\mathrm{kwaad}$ te stuiten. Wij treden thans niet in eene beoordeeling, maar wenschen alleen dit punt te constateeren, daar het een verrassend licht werpt over de gedragslijn die de Bank in 1865 heeft gevolgd.

En thans een wensch. De Bank-directie heeft ditmal in haar verslag uitroeriger mededeelingen gedaan omtrent de disconto's dan vroeger, door ons bekend te maken met hetgeen, an wissels en hetgeen aan ander handelspapier is gedisconteerd. Ook heeft zij ons tabellen gegeven, waaruit wij kunnen opmaken hoeveel op. den laatsten dag van elke maand de beleeningen op effecten en die op goederen hebben bedragen. Zou het nu niet mogelijk zijn dat wij elke week soortgelijke inlichtingen ontvingen, zoodat wij niet langer telkens in twijfel behoefden te staan over het aandeel dat van de disconto's an wissels en ander papier en van de beleeningen, aan goederen en effecten toekomt. Het zou, meenęn wij, aan de Bank weinig moeite kosten dien wensch to bevredigen, en zij die gewoon zijn de weekstaten met aandacht na te gaan, zouden er reel bij winnen. $\mathrm{Zij}$ zouden dan beter in staat zijn te beoordeelen uit welke oorzaken de veranderingen, die in den toestand der Bank plaats grijpen, voortvloeien, en niet, gelijk nu dikwijls het geval is, ann onzekerheid zijn prijs gegeven. 